\title{
Peran Badan Permusyawaratan Desa di Dalam Pembangunan Desa dan Pengawasan Keuangan Desa
}

\author{
Darmini Roza* dan Laurensius Arliman S** \\ DOI: https://doi.org/10.22304/pjih.v4n3.a10
}

\begin{abstract}
Abstrak
Pemberlakuan Undang-Undang Nomor 6 Tahun 2014 tentang Desa berimplikasi pada kucuran dana miliaran rupiah langsung ke desa yang bersumber dari alokasi dana desa. Kepala desa sebagai pemimpin desa harus dapat menerapkan fungsi manajemen sejak perencanaan, pengorganisasian, penggerakan, dan pengawasan untuk mengatur desanya supaya lebih maju. Berdasarkan peraturan per-UU-an yang ada, pemerintah desa dibantu oleh Badan Permusyawaratan Desa. Tulisan ini menyajikan peran vital BPD sebagai penerus aspirasi masyarakat di dalam pemerintahan desa. Artinya, BPD bukanlah lembaga yang dapat dengan begitu saja disepelekan, melainkan kepala desa harus senantiasa bekerja sama dengan BPD dalam pembangunan desa. Akhir penulisan ini menjelaskan tentang pengawasan keuangan yang dilakukan oleh BPD. Pelaksanaan pengawasan juga dapat mendeteksi, sejauh mana kebijakan kepala desa untuk menjalankan dan penyimpangan keuangan yang terjadi dalam pelaksanaan kerja tersebut. Tulisan ini juga menegaskan bahwa faktor yang dapat mendukung pengawasan BPD adalah masyarakat, karena masyarakat merupakan faktor penentu keberhasilan BPD dalam melaksanakan pengawasan keuangan desa.
\end{abstract}

Kata kunci: Badan Permusyawaratan Desa, desa, keuangan desa, pengawasan, pembangunan desa.

\section{The Role of Village Consultative Board in Village Development and Village Finance Supervision}

\begin{abstract}
The enactment of Law Number 6 Year 2014 on Village implies the disbursement of billions of rupiah funds directly to the villages sourced from the allocation of village funds. The village head as a village leader should be able to implement the management function from planning, organizing, mobilizing, and supervising to organize his village to be more advanced. Under the existing law, the village government is assisted by the Village Consultative Board (Badan Permusyawaratan Desa). This paper presents the vital role of BPD as the successor to the aspirations of the people in the village administration. BPD is not an institution that can be underestimated, but the village head should always work with BPD in rural development. The end of this paper describes the financial supervision made by BPD. The implementation of supervision can also detect to what extent the policy of the village head is to run and the financial irregularities that occur in the implementation of such work. This paper also

PADJADJARAN Jurnal IImu Hukum Volume 4 Nomor 3 Tahun 2017 [ISSN 2460-1543] [e-ISSN 2442-9325]

* Guru Besar Universitas Ekasakti, Jl. Veteran Dalam No.26B, Padang Pasir, Kota Padang, Sumatera Barat, S.H (Universitas Taman Siswa), M.H., Dr. (Universitas Padjadjaran).

** Dosen STIH Padang, Jl. Gang Mesid Baiturahman No.40, Kota Padang, Sumatera Barat, laurensiusarliman@ gmail.com, S.H (Universitas Andalas), S.E. (STIE Pelita Bangsa), M.Kn. (Universitas Andalas), M.H. (Universitas Ekasakti).
\end{abstract}


confirms that the factors that can support BPD supervision is the community, because the community is a critical determinant of the success of BPD in implementing village financial oversight.

Keywords: Village Consultative Board, village, village finance, supervision, village development.

\section{A. Latar Belakang}

Pembentuk Undang-Undang Dasar Negara Republik Indonesia Tahun 1945 (UUD 1945) mempertahankan pemerintahan desa bukanlah dalam semangat agar desa tetap asli menjalankan fungsi pemerintahan tradisional sebagai masyarakat hukum adat, melainkan dimaksudkan untuk menjamin kehadiran satuan pemerintah yang dekat dengan rakyat. Selain itu desa sebagai satuan pemerintahan demokratis dapat menjadi model pengembangan demokrasi, seperti penerapan prinsip permusyawaratan, kolektivitas, kekeluargaan, dan lain sebagainya. ${ }^{1}$ Bahkan Soepomo menyatakan Negara Republik Indonesia sebagaimana kemudian diproklamasikan tanggal 17 Agustus 1945, maka dalam Negara Republik Indonesia (RI) tersebut bangsa Indonesia berdasarkan atas teori negara 'Republik Desa'. ${ }^{2}$ Baik mengenai hakikat RI yang didalamnya terkandung cita negaranya, mengenai pembenaran adanya RI, maupun mengenai tujuan RI, ternyata semua itu sama dengan hakikat, pembenaran adanya, terbentuknya, dan tujuan dari desa. Semua itu tentunya dalam lingkup yang jauh lebih besar dan dalam konstelasi yang lebih modern, sesuai dengan zaman dan masa diproklamasikannya RI. ${ }^{3}$ Salah satu perjalanan menguatkan desa di Indonesia bisa dilihat dengan dikuatkannya desa dalam suatu bentuk otonomi daerah yang diberikan oleh pemerintah, yang dulu bersifat sentralistik sekarang menjadi desentralistik.

Perjalanan otonomi daerah di Indonesia merupakan isu menarik untuk diamati dan dikaji, karena semenjak para pendiri negara menyusun format negara, isu menyangkut pemerintahan lokal telah diakomodasi dalam Pasal 18 UUD 1945 beserta penjelasannya. Pemerintahan daerah dalam pengaturan Pasal 18 UUD 1945 telah mengakui adanya keragaman dan hak asal-usul yang merupakan bagian dari sejarah panjang bangsa Indonesia. Sehingga meskipun RI menganut prinsip negara kesatuan dengan pusat kekuasaan berada pada pemerintah pusat, namun karena heterogenitas (keragaman) yang dimiliki bangsa Indonesia, baik kondisi sosial, ekonomi, budaya, agama, suku bangsa, maupun keragaman tingkat pendidikan masyarakat, maka desentralisasi atau distribusi kekuasaan atau kewenangan dari pemerintah pusat, perlu dialirkan kepada daerah yang bersifat otonomi. ${ }^{4}$ Secara

I Gde Pantja Astawa, Problematika Otonomi di Daerah di Indonesia, Bandung: Alumni, 2013, hlm. 326-327.

A.T. Soegito, Prof. Mr. Dr. R. Soepomo, Jakarta: Departemen Pendidikan dan Kebudayaan Pusat Penelitian Sejarah dan Budaya Proyek Investarisasi dan Dokumen Sejarah Nasional, 1979-1980, hlm. 4-5.

3 A. Hamid S Attamimi, "Peranan Keputusan Presiden Republik Indonesia dalam Penyelenggaraan Pemerintahan Negara, Suatu Studi Analisis Mengenai Keputusan Presiden yang Berfungsi Pengaturan dalam Ukuran Waktu Pelita I-IV", Disertasi, Pascasarjana Fakultas Hukum Universitas Indonesia, Jakarta, 1990, hlm. 101-102.

4 J. Kaloh, Mencari Bentuk Otonomi Daerah, Suatu Solusi Dalam Menjawab Kebutuhan Lokal dan Tantangan 
teoretis dan faktual, pembentukan daerah otonom melalui desentralisasi, tidak akan menjadi penyebab terjadinya disintegrasi nasional, tetapi justru sangat kondusif bagi tercapainya integrasi nasional.

Bagir Manan menyatakan bahwa pemahaman hubungan pemerintah pusat dan pemerintah daerah yang bersifat hierarkis dan vertikal di satu pihak, berhadapan dengan pemahaman yang bersifat horisontal di lain pihak dan tidak tegasnya asas dekonsentrasi di dalam Pasal 18 UUD 1945 setelah amandemen kedua akan menimbulkan persoalan antara pemerintahan pusat dan pemerintahan daerah yang bersumber pada hubungan keuangan, hubungan kewenangan, hubungan pengawasan dan hubungan yang timbul dari susunan organisasi pemerintahan di daerah. ${ }^{5}$ Pemberian otonomi kepada kelompok-kelompok masyarakat di wilayah masing-masing akan mendorong warga masyarakat berpartisipasi untuk membangun daerahnya. Dengan demikian akan terwujud unity within diversity dan diversity in unity. ${ }^{6}$ Menurut UUD 1945, pengakuan terhadap kesatuan masyarakat hukum adat termasuk di dalamnya adalah desa beserta hak-hak tradisionalnya harus didasarkan pada prinsip tetap dalam bingkai Negara Kesatuan Republik Indonesia (NKRI). ${ }^{7}$

Menurut Ateng Syafrudin, reformasi otonomi daerah yang sejak lama dilakukan adalah mengutamakan keseragaman, lebih realistis, dan bermanfaat, jika ke-bhinekaan, kondisi tiap daerah diseleksi hal-hal yang perlu dibiarkan dan dipupuk, potensi sumber daya alam, dan nilai budaya lokalnya, sehingga dalam rangka berotonominya suatu daerah, dapat dijadikan unggulan yang menjadikan kebanggaan daerahnya. Karena itu, dalam kondisi fisik daerah yang berbeda-beda akan disikapi secara realistis dengan intensitas meningkatkan kemanfaatannya tetap diperlukan, dengan meningkatkan kualitas dan kuantitas infrastruktur yang lebih kontributif bagi pertumbuhan ekonomi daerah (desa). ${ }^{8}$

Secara filosofis, keberadaan desa menunjukkan lebih dahulu ada dan perannya dalam berpemerintahan dengan rakyat, sebelum muncul tata pemerintahan di atasnya. Oleh karena itu, desa seharusnya menjadi landasan dan bagian dari tata pengaturan pemerintahan sesudahnya. Bangunan pemerintahan desa merupakan hal yang fundamental bagi tata negara Indonesia; artinya, bangsa dan negara sebenarnya terletak di desa. Oleh karena itu, pengaturan desa dalam perundangundangan, baik jenis dan hierarkinya, akan menentukan maju mundurnya desa yang berimplikasi pada pemerintahan yang ada di atasnya. Undang-undang (UU) tentang pemerintahan desa, merupakan instrumen untuk membangun kehidupan baru desa yang mandiri, demokratis, dan sejahtera. Kemandirian yang dimaksud bukan

Global, Jakarta: PT. Rineka Cipta, 2007, hlm. 1.

5 Bagir Manan, Menyongsong Fajar Otonomi Daerah, Yogyakarta: Pusat Studi Hukum Fakultas UII Yogyakarta, 2002, hlm. 36.

6 Didik Sukrino, Hukum Konstitusi dan Konsep Otonomi, Kajian Politik Hukum Tentang Konstitusi, Otonomi Daerah dan Desa Pasca Perubahan Konstitusi, Malang: Setara Press, 2013, hlm. 125.

7 Ateng Syafrudin dan Suprin Na'a, Republik Desa: Pergulatan Hukum Tradisional dan Hukum Modern Dalam Desain Otonomi Desa, Bandung: Alumni, 2010, hlm. 43.

8 Ateng Syafrudin, "Prolog", dalam buku Otonomi Daerah dan Kepala Daerah Memasuki Abad XXI, yang disusun oleh Andi Mustari Pide, Jakarta: Gaya Media Pratama, 1999, hlm. xiv. 
kesendirian desa dalam menghidupi dirinya sendiri, tetapi terkait degan dimensi keadilan yang berada dalam konteks relasi antara desa dengan supradesa (pusat dan daerah).

Kemandirian desa berarti kapasitas dan inisiatif lokal yang kuat dalam gagasan, kehendak, dan kemauan desa yang berbasis pada kearifan lokal, komunalisme, dan modal sosial. Sementara itu demokrasi adalah nilai dan sistem yang memberi bingkai tata pemerintahan desa. Secara konseptual, demokrasi mengandung sejumlah prinsip dasar representasi, transparansi, akuntabilitas, responsivitas, dan partisipasi, yang selanjutnya menjadi dasar pengelolaan kebijakan, perencaaan desa, pengelolaan keuangan desa, dan pelayanan publik menuju kesejahteraan rakyat, yang meliputi dua komponen besar (pangan, papan, pendidikan, dan kesehatan), dan pengembangan ekonomi desa yang berbasis pada potensi lokal. ${ }^{9}$

Dalam perjalanan ketatanegaraan pemerintahan desa, telah ditetapkan beberapa peraturan perundang-undangan yang mengatur tentang desa, antara lain: Undang-Undang Nomor 5 Tahun 1974 tentang Pokok-Pokok Pemerintahan Di Daerah, Undang-Undang Nomor 5 Tahun 1979 tentang Pemerintahan Desa (UU Pemerintahan Desa 1979), Undang-Undang Nomor 22 Tahun 1999 tentang Pemerintahan Daerah (UU Pemda 1999), Undang-Undang Nomor 32 tahun 2004 tentang Pemerintahan Daerah (UU Pemda 2004), dan terakhir desa memiliki undangundang sendiri yaitu Undang-Undang Nomor 6 Tahun 2014 tentang Desa (UU Desa) dan ditegaskan kembali di dalam Undang-Undang Nomor 23 Tahun 2014 tentang Pemerintahan Daerah, dimana pengakuan keberadaan desa ditegaskan dalam Pasal 2 yang menyatakan bahwa: “(1) Negara Kesatuan Republik Indonesia dibagi atas Daerah Kabupaten dan Kota; (2) Daerah Kabupaten/Kota dibagi atas Kecamatan dan Kecamatan dibagi atas Kelurahan dan/atas Desa". Demikian pula dalam Pasal 371 menyatakan bahwa: “1) Dalam Daerah Kabupaten/Kota dapat dibentuk Desa, 2) Desa sebagaimana dimaksud pada ayat (1) mempunyai kewenangan sesuai dengan ketentuan peraturan perundang-undangan mengenai Desa".

UU Desa ini membawa semangat dan harapan baru untuk mewujudkan desa yang mandiri. Diharapkan segala kepentingan dan kebutuhan masyarakat desa dapat diakomodasi dengan lebih baik. Pemberian kesempatan yang lebih besar kepada desa untuk mengurus tata pemerintahannya sendiri serta pemerataan pelaksanaan pembangunan diharapkan dapat meningkatkan kesejahteraan dan kualitas hidup masyarakat desa, sehingga permasalahan seperti kesenjangan antar wilayah, kemiskinan dan masalah sosial budaya lainnya dapat diminimalisasi. UU Desa beserta peraturan pelaksananya telah mengamanatkan pemerintah desa untuk lebih mandiri dalam mengelola pemerintahan dan berbagai sumber daya alam yang dimiliki, termasuk kemandiriannya dalam tata kelola keuangan.

Pasal 1 ayat (2) Peraturan Pemerintah Nomor 60 Tahun 2014 tentang Dana Desa yang Bersumber dari Anggaran Pendapatan Belanja Negara (PP 60/2014), menyatakan bahwa dana desa adalah dana yang bersumber dari Anggaran

Didik Sukrino, Op.cit., hIm. 183. 
Pendapatan dan Belanja Negara (APBN) dan dana tersebut ditransfer lewat Anggaran Pendapatan dan Belanja Daerah (APBD) kabupaten/kota, yang selanjutnya ditransfer ke APB Desa. Dana desa yang bersumber dari APBN hanya diperuntukkan bagi desa digunakan untuk membiayai penyelenggaraan pemerintah desa, pelaksanaan pembangunan, pembinaan kemasyarakatan, dan pemberdayaan masyarakat. Pattiro berpendapat bahwa desa mendapatkan gelontoran dana yang cukup besar yang salah satunya berasal dari APBN dan bertujuan untuk meningkatkan kesejahteraan masyarakat, karena hakikat anggaran adalah anggaran bersumber dari uang rakyat yang dikelola oleh pemerintah dalam bentuk APBD dan APBN untuk kesejahteraan rakyat. Oleh karena itu, rakyat berhak mengetahui alokasi dana yang dibelanjakan oleh pemerintah. ${ }^{10}$

Pengaturan desa yang baru ini berpengaruh juga pada perubahan mekanisme tata kelola keuangan di desa yang diatur melalui Peraturan Menteri Dalam Negeri Nomor 113 Tahun 2014 tentang Pedoman Pengelolaan Keuangan Desa, karena pengelolaan keuangan merupakan hal yang paling sensitif dalam tata kelola pemerintahan desa, maka pengaturannya harus transparan, partisipatif, akuntabel serta dilakukan tertib dan disiplin anggaran. Sumber keuangan desa sebagaimana dijelaskan dalam Pasal 76 ayat (1) UU Desa terdiri dari: pendapatan asli desa, dana transfer (dana desa, alokasi dana Desa/ADD, bagi hasil pajak dan retribusi daerah), bantuan keuangan dan pendapatan desa lain yang sah. Peran besar yang diterima oleh desa tentunya disertai dengan tanggung jawab yang besar pula. Oleh karena itu pemerintah desa harus bisa menerapkan prinsip akuntabilitas dalam tata pemerintahannya, yang mana semua akhir kegiatan penyelenggaraan pemerintah desa dapat dipertanggungjawabkan kepada masyarakat desa sesuai dengan ketentuan. ${ }^{11}$

Di samping mengatur mengenai kedudukan, fungsi, dan peran pemerintahan desa, UU Desa juga menjelaskan bagaimana keterwakilan dari penduduk dengan pembentukan Badan Permusyawaratan Desa (BPD). Pasal 1 angka 4 UU Desa menyatakan BPD atau yang disebut dengan nama lain adalah lembaga yang melaksanakan fungsi pemerintahan yang anggotanya merupakan wakil dari penduduk desa berdasarkan keterwakilan wilayah dan ditetapkan secara demokratis.

BPD ini memiliki fungsi strategis dalam penetapan kebijakan desa serta pengawasan yang dilakukannya kepada pemerintah desa karena fungsinya selaku badan pengawas. Pengawasan terhadap pelaksanaan pemerintahan merupakan salah satu alasan terpenting mengapa BPD perlu dibentuk. Upaya pengawasan dimaksudkan untuk mengurangi adanya penyelewengan atas kewenangan dan keuangan desa dalam penyelenggaraan pemerintahan desa. ${ }^{12}$ Pasal 55 UU Desa

10 Robi Syafwar, "Pengawasan Pengelolaan Keuangan Nagari Oleh Badan Permusyawaratan Nagari Di Kabupaten Agam”, Tesis, Pascasarjana Fakultas Hukum Universitas Andalas, Padang, 2017, hlm. 6.

11 Ibid., hlm. 7.

12 Dian Haryani, “Peran Badan Permusyawaratan Desa Dalam Pengawasan Penyelenggaraan Pemerintahan Desa di Desa Melati II Kecamatan Perbaungan Kabupaten Serdang Bedagai", Jurnal Perspektif, Vol. 8, No. 1, 2015, hlm 427. 
menyatakan bahwa BPD mempunyai fungsi: a) membahas dan menyepakati rancangan peraturan desa bersama kepala desa; b) menampung dan menyalurkan aspirasi masyarakat desa; dan c) melakukan pengawasan kinerja kepala desa.

Merujuk pada ketiga fungsi tersebut, pada hakikatnya BPD menjadi lembaga yang menjalankan mekanisme check and balances dalam penyelenggaraan pemerintahan desa. Setidaknya jika mengacu pada proses pembahasan UU Desa itu sendiri. Pembahasan RUU Desa antara Dewan Perwakilan Daerah (DPD), Dewan Perwakilan Rayat (DPR) dan pemerintah. Jacob Jack Ospara yang mewakili DPD menegaskan bahwa pemerintahan desa yang kuat bukan dalam pengertian bentuk pemerintahan yang otoritas (misalnya dengan masa jabatan yang terlalu lama), namun bentuk pemerintahan desa dengan tata pemerintahan yang demokratis yang dikontrol (check and balances) oleh institusi lokal seperti BPD atau badan musyawarah serta elemen masyarakat setempat. ${ }^{13}$

Masyarakat desa sangat berharap agar BPD bisa menjalankan fungsinya dalam bidang pengawasan terutama penggunaan dana desa. Hal ini sebagai konsekuensi atas berlakunya UU Desa dikarenakan adanya kucuran dana miliaran rupiah langsung ke desa yang bersumber dari alokasi dana desa yang merupakan bagian dari dana perimbangan yang diterima kabupaten/kota.

Banyaknya sumber keuangan yang diperoleh desa, maka penggunaannya dan pengelolaannya akan bervariasi juga. Dengan kompleksnya keuangan desa yang harus dikelola, maka dapat dipertanyakan mengenai masih mampukah BPD dengan segala keterbatasan untuk mengawasi dana tersebut, di mana BPD merupakan wujud dari perwakilan masyarakat, karena seringkali yang menjadi perdebatan dalam UU Desa adalah ketidak-optimalan kinerja dari BPD yang sebenarnya menjadi faktor penting dari implementasi UU. Kinerja BPD dalam mengontrol pemerintahan desa dari segi pengelolaan pengawasan keuangan perlu ditingkatkan dari berbagai aspek, untuk mewujudkan pembangunan desa yang sejahtera yang akan dibahas dalam tulisan ini.

\section{B. Peran Badan Permusyawaratan Desa dalam Pemerintahan Desa}

Pasal 1 angka 1 UU Desa menyatakan:

"Desa adalah desa dan desa adat atau yang disebut dengan nama lain, selanjutnya disebut Desa, adalah kesatuan masyarakat hukum yang memiliki batas wilayah yang berwenang untuk mengatur dan mengurus urusan pemerintahan, kepentingan masyarakat setempat berdasarkan prakarsa masyarakat, hak asal usul, dan/atau hak tradisional yang diakui dan dihormati dalam sistem pemerintahan Negara Kesatuan Republik Indonesia."

Selanjutnya, angka 2 menyatakan: "Pemerintahan desa adalah penyelenggaraan urusan pemerintahan dan kepentingan masyarakat setempat dalam sistem pemerintahan NKRI". Adapun yang disebut pemerintahan desa diatur dalam Pasal

$13 \quad$ Robi Syafwar, Op.cit., hlm. 8. 
3, yaitu "Kepala desa atau yang disebut dengan nama lain, dibantu perangkat desa sebagai unsur penyelenggara pemerintahan desa". Salah satu unsur penyelenggara tersebut adalah BPD yang dijelaskan dalam Pasal 1 angka 4 UU Desa. Setidaknya BPD dalam UU Desa disebutkan sebanyak 41 kali. Hal ini menandakan betapa peran penting BPD dalam pengelolaan pemerintahan desa.

Selanjutnya, Pasal 24 UU Desa menyatakan: "Penyelenggaraan pemerintahan desa berdasarkan asas: a) kepastian hukum; b) tertib penyelenggaraan pemerintahan; c) tertib kepentingan umum; d) keterbukaan; e) proporsionalitas; f) profesionalitas; g) akuntabilitas; h) efektivitas dan efisiensi; i) kearifan lokal; j) keberagaman; dan k) partisipatif". Bahkan di dalam Pasal 32 dijelaskan bagaimana peran BPD dalam penyelenggaran pemerintahan desa, terutama dalam pemilihan kepala desa, yang nantinya menjadi pemimpin pemerintahan desa. Dalam pasal itu dinyatakan bahwa:

“(1) Badan Permusyawaratan Desa memberitahukan kepada Kepala Desa mengenai akan berakhirnya masa jabatan Kepala Desa secara tertulis 6 bulan sebelum masa jabatannya berakhir.

(2) Badan Permusyawaratan Desa membentuk panitia pemilihan Kepala Desa.

(3) Panitia pemilihan Kepala Desa sebagaimana dimaksud pada ayat (2) bersifat mandiri dan tidak memihak.

(4) Panitia pemilihan Kepala Desa sebagaimana dimaksud pada ayat (3), terdiri atas unsur perangkat Desa, lembaga kemasyarakatan, dan tokoh masyarakat Desa."

Keanggotaan BPD sendiri diatur dalam Pasal 56 yang menyatakan:

“(1) Anggota Badan Permusyawaratan Desa merupakan wakil dari penduduk Desa berdasarkan keterwakilan wilayah yang pengisiannya dilakukan secara demokratis.

(2) Masa keanggotaan Badan Permusyawaratan Desa selama 6 tahun terhitung sejak tanggal pengucapan sumpah/janji.

(3) Anggota Badan Permusyawaratan Desa sebagaimana dimaksud pada ayat (1) dapat dipilih untuk masa keanggotaan paling banyak 3 kali secara berturut-turut atau tidak secara berturut-turut."

Persyaratan menjadi anggota BPD juga ditentukan secara khusus, dengan tujuan agar mendapatkan anggota BPD yang proporsional dan mau bergerak aktif untuk mengawasi pemerintahan desa untuk mewujudkan desa yang sejahtera sebagaimana dicita-citakan oleh masyarakat.

Adapun syarat-syarat menjadi anggota BPD tertuang dalam Pasal 57 yang menyatakan bahwa:

1) bertakwa kepada Tuhan Yang Maha Esa;

2) memegang teguh dan mengamalkan Pancasila, melaksanakan UUD 1945, serta mempertahankan dan memelihara keutuhan NKRI dan Bhinneka Tunggal Ika;

3) berusia paling rendah 20 tahun atau sudah/pernah menikah;

4) berpendidikan paling rendah tamat sekolah menengah pertama atau sederajat; 
5) bukan sebagai perangkat pemerintah desa;

6) bersedia dicalonkan menjadi anggota BPD; dan

7) wakil penduduk desa yang dipilih secara demokratis.

Selanjutnya, Pasal 60 menyatakan bahwa BPD menyusun peraturan tata tertib BPD. Pasal 61 mengatur hak-hak BPD yakni:

1) mengawasi dan meminta keterangan tentang penyelenggaraan pemerintahan desa kepada pemerintah desa;

2) menyatakan pendapat atas penyelenggaraan pemerintahan desa, pelaksanaan pembangunan desa, pembinaan kemasyarakatan desa, dan pemberdayaan masyarakat desa; dan

3) mendapatkan biaya operasional pelaksanaan tugas dan fungsinya dari APBD.

Selain itu, Pasal 62 juga menyatakan bahwa BPD berhak untuk: 1) mengajukan usul rancangan peraturan desa; 2) mengajukan pertanyaan; 3) menyampaikan usul dan/atau pendapat; 4) memilih dan dipilih; dan 5) mendapat tunjangan dari APBD. Menyangkut kewajiban BPD tertuang dalam Pasal 63 yang menyatakan bahwa anggota BPD wajib:

1) memegang teguh dan mengamalkan Pancasila, melaksanakan UUD 1945, serta mempertahankan dan memelihara keutuhan NKRI dan Bhinneka Tunggal Ika;

2) melaksanakan kehidupan demokrasi yang berkeadilan gender dalam penyelenggaraan pemerintahan desa;

3) menyerap, menampung, menghimpun, dan menindaklanjuti aspirasi masyarakat desa;

4) mendahulukan kepentingan umum di atas kepentingan pribadi, kelompok, dan/ atau golongan;

5) menghormati nilai sosial budaya dan adat istiadat masyarakat desa; dan

6) menjaga norma dan etika dalam hubungan kerja dengan lembaga kemasyarakatan desa.

Bahkan untuk memaksimalkan anggota BPD dalam keikutsertaannya membangun pemerintahan desa yang terbuka dan efisien, anggota BPD memiliki beberapa larangan. Hal ini untuk menjelaskan kenetralan anggota BPD dalam bekerja dan tidak memberikan keuntungan hanya kepada dirinya sendiri. Hal ini tertuang dalam Pasal 64 UU Desa yang menyatakan bahwa anggota BPD dilarang:

a) merugikan kepentingan umum, meresahkan sekelompok masyarakat desa, dan mendiskriminasikan warga atau golongan masyarakat desa;

b) melakukan korupsi, kolusi, dan nepotisme, menerima uang, barang, dan/atau jasa dari pihak lain yang dapat memengaruhi keputusan atau tindakan yang akan dilakukannya;

c) menyalahgunakan wewenang;

d) melanggar sumpah/janji jabatan;

e) merangkap jabatan sebagai kepala desa dan perangkat desa;

f) merangkap sebagai anggota DPR, DPRD Provinsi, DPRD Kabupaten/Kota, dan jabatan lain yang ditentukan dalam peraturan perundangan-undangan; 
g) sebagai pelaksana proyek desa;

h) menjadi pengurus partai politik; dan/atau

i) menjadi anggota dan/atau pengurus organisasi terlarang.

Hal ini untuk membuat masyarakat desa percaya bahwa BPD adalah sebuah lembaga yang mementingkan kepentingan pemerintahan desa dan kepentingan masyarakat desa.

BPD bukan lembaga baru. Dalam 15 tahun terakhir, tugas, fungsi, dan kedudukan BPD terus berubah-ubah. Perubahan ini dilakukan untuk menuju BPD yang lebih baik lagi. Perubahan terhadap BPD ini juga tidak terlepas dari perubahan regulasi yang mengatur tentang urusan desa. Perubahan tugas dan fungsi BPD ini berpengaruh pada pasang naik dan surutnya demokrasi di desa. Desa sebagai republik kecil mengandaikan setiap warganya memiliki hak untuk terlibat dalam penyelenggaraan pemerintahan dan pembangunan. Karena itu, lembaga BPD menjadi lembaga demokrasi perwakilan di tingkat desa. Istilah Badan Perwakilan Desa sendiri diperkenalkan oleh UU Pemda 1999 sebagai lembaga legislatif desa, dan hal ini diatur di dalam Pasal 104 UU Pemda 1999. Peran BPD sebagai lembaga legislatif yang kuat di tingkat desa, selanjutnya diatur kembali oleh UU Pemda 2004. BPD bergeser menjadi unsur pemerintahan desa, dengan konsekuensi berwenang dan ikut mengatur dan mengurus desa.

Perubahan kelembagaan tersebut tidak hanya berdampak positif dalam pelaksanaan pemerintahan desa, tetapi juga dalam pemantauan di desa. Di samping itu juga menimbulkan efek negatif dalam hubungan antar-lembaga di desa dan bahkan terhadap masyarakat secara umum. Tingkat pemahaman aparatur desa dan anggota BPD dalam menjalankan mekanisme demokrasi di tingkat desa juga menjadi penyebab munculnya berbagai konflik dalam hubungan antar-lembaga di desa. Sebagai daerah otonom, desa mempunyai kewenangan yang luas dan tanggung jawab yang besar untuk melaksanakan kepentingan masyarakat berdasarkan prinsip-prinsip keterbukaan, partisipasi masyarakat dan pertanggungjawaban kepada masyarakat.

Dalam kedudukan yang sejajar dengan pemerintahan desa, BPD menjadi mitra kerja pemerintahan desa dan dapat menjalankan fungsinya sebagai lembaga yang mengawasi jalannya pemerintahan desa. Berdasarkan kedudukannya itu, BPD pada dasarnya memiliki tugas-tugas pokok untuk: 1) merumuskan peraturan-peraturan (legislating function) yang dibutuhkan oleh desa, yang nantinya disahkan oleh Surat Keputusan Kepala Desa; 2) bersama-sama kepala desa membuat Anggaran Penerimaan dan Pengeluaran Keuangan Desa (budgetting function); dan 3) mengawasi eksekutif desa (kepala desa beserta perangkatnya) dalam pelaksanaan pemerintahan sehari-hari (controlling function). ${ }^{14}$

14 Findy Yanel Mamesah, "Peranan Badan Permusyawaratan Desa dalam Penyusunan Anggaran Pendapatan dan Belanja Daerah (Suatu Studi di Desa Sendangan Kecamatan Tompaso)", Skripsi, Fakultas Hukum Universitas Sam Ratulangi Manado, 2014, hlm. 8. 
Meski BPD sebagai lembaga yang merupakan perwujudan demokrasi dalam penyelenggaraan pemerintahan desa sebagai unsur penyelenggara pemerintahan desa. BPD berfungsi menetapkan peraturan desa bersama kepala desa, menampung dan menyalurkan aspirasi masyarakat. Penyelenggaraan pemerintahan di desa tidak terlepas dari keterlibatan kelembagaan desa yang berwujud BPD. Tetapi tetap saja BPD masih memiliki kelemahan di dalam keikutsertaannya dalam pemerintahan desa, antara lain: ${ }^{15}$ 1) Kondisi BPD di desa-desa masih memerlukan penguatan kelembagaan, terutama dalam melakukan legislasi mulai dari penyusunan sampai ke pengawasan peraturan desa; 2) Masih perlu meningkatkan peran pengawasan BPD didalam membuat kebijakan-kebijakan pemerintah desa, hal ini mengingat makin luas dan kompleksnya permasalahan serta tuntutan yang dihadapi oleh masyarakat khususnya masyarakat tingkat bawah di desa; 3) Pada bagian lain seperti dalam hubungan antar kelembagaan desa seperti BPD dan kepala desa yang terkadang hubungannya tidak harmonis, maka dari itu harus ada pendekatan yang efisien yang harus dilakukan oleh pemerintah, untuk mendudukan hal tersebut. Hal ini tentu akan membuat peran BPD dalam pemerintahan desa menjadi lebih baik lagi.

\section{Peran Badan Permusyawaratan Desa dalam Pembangunan Desa}

Kata peranan ini sebenarnya menunjukan pada aktivitas yang dilakukan seseorang untuk melakukan sesuatu dalam kelompok masyarakat. Dengan demikian kata peran berarti sesuatu berupa orang, benda atau barang yang memegang pimpinan atau karena suatu hal atau peristiwa. ${ }^{16}$ Peran BPD dalam pembangunan desa dapat dilihat bagaimana pembangunan masyarakat desa itu sendiri. Pembangunan masyarakat desa diidentifikasi dengan perbaikan setiap bentuk usaha-usaha setempat yang bisa dicapai dengan keinginan masyarakat untuk bekerja sama. Berhasilnya BPD akan dipengaruhi oleh sikap masyarakat terhadapnya. Apabila sikap ini menguntungkan maka nampaknya masyarakat itu akan bertindak sesuai dengan saran badan tersebut, sekurang-kurangnya mendengarkannya. BPD harus lebih banyak memperhitungkan, tidak hanya memperhitungkan kebutuhan masyarakat, adat-istiadat, norma-norma dan kepercayaan saja. BPD harus mengenal seluruh aspek kebudayaan masyarakat tradisional, yang dalam beberapa hal bertautan antara satu dengan yang lain, dan perubahan dalam satu aspek kebudayaan itu akan mempengaruhi aspek-aspek lainnya dan menimbulkan masalah baru. ${ }^{17}$

Pengakuan secara yuridis terhadap kewenangan BPD terhadap pembangunan desa tidak akan banyak artinya apabila tidak didukung dengan pemberian sumber-sumber pembiayaan serta upaya pemberdayaan secara konseptual dan berkesinambungan. Sebab pada dasarya pembiayaan akan mengikuti fungsi-

15 Andri Paraso, "Efektivitas Badan Permusyawaratan Desa dalam Penyelenggaraan Pengawasan Pemerintahan di Desa Sareh (Suatu Studi di Desa Sereh Kecamatan Lirung Kabupaten Kepulauan Talaud)", Jurnal Eksekutif, Vol. 2, No. 1, 2013, hlm. 1-10.

16 Kamus Besar Bahasa Indonesia, "Peran”, https://kbbi.kemdikbud.go.id/entri/peran diakses 11 September 2017.

17 A. Surjadi, Pembangunan Masyarakat Desa, Bandung: Mandar Maju, 1995, hlm. 13. 
fungsi yang dijalankan (money follow function). Sedangkan upaya pemberdayaan masyarakat dan pemerintah Desa perlu dilakukan secara kasus demi kasus berdasarkan karakteristik desa masing-masing. Upaya pemberdayaan desa secara seragam dan serentak hanya akan menghasilkan perubahan semu saja. Maksudnya, berbagai perubahan terjadi hanya pada saat ada upaya pemberdayaan dari pihak luar desa dan supradesa, dan akan kembali ke pola lama pada saat kekuatan dari luar berhenti mendorongnya. ${ }^{18}$

Pasal 78 ayat 1 dan 2 UU Desa mengatakan pembangunan desa bertujuan meningkatkan kesejahteraan masyarakat desa dan kualitas hidup manusia serta penanggulangan kemiskinan melalui pemenuhan kebutuhan dasar, pembangunan sarana dan prasarana desa, pengembangan potensi ekonomi lokal, serta pemanfaatan sumber daya alam dan lingkungan secara berkelanjutan. Pembangunan desa meliputi tahap perencanaan, pelaksanaan, dan pengawasan.

Pembangunan desa sebagaimana dimaksud pada ayat (2) mengedepankan kebersamaan, kekeluargaan, dan kegotongroyongan guna mewujudkan pengarusutamaan perdamaian dan keadilan sosial. Oleh sebab itu, dapat diketahui bahwa suatu perencanaan pembangunan, khususnya perencanaan pembangunan desa sangat membutuhkan pendekatan yang menyeluruh. Perencanaan pembangunan desa merupakan perencanaan pembangunan yang dilakukan masyarakat sendiri, dari dan untuk masyarakat sendiri, dengan pengarahan, bimbingan, bantuan, dan pembinaan serta pengawasannya dilakukan oleh pemerintah. Jadi, dengan proses pembangunan yang seperti ini apa yang menjadi harapan dan keinginan masyarakat desa dapat terpenuhi dan diwujudkan dalam bentuk nyata berlandaskan musyawarah. Musyawarah merupakan salah satu asas dasar negara Indonesia. Musyarawah pembangunan yang diadakan oleh pemerintah desa disebut Musyawarah Perencanaan Pembangunan (Musrenbang) desa. ${ }^{19}$

Musrenbang desa dalam penjelasannya pada Buku 1 tentang Panduan Penyelenggaraan Musyawarah Perencanaan Pembangunan Desa atau Kelurahan tahun 2008 adalah forum musyawarah tahunan para pemangku kepentingan (stakeholder) menyepakati rencana kegiatan untuk tahun anggaran berikutnya. Musrenbang desa atau kelurahan dilakukan setiap bulan Januari untuk menyusun rencana kegiatan tahunan desa dengan mengacu atau memperhatikan kepada Rencana Pembangunan Jangka Menengah-Desa (RPJM-Desa) yang sudah disusun. Musrenbang yang bermakna akan membangun kesepahaman tentang kepentingan dan kemajuan desa, dengan memotret potensi dan sumber-sumber pembangunan yang tersedia baik dari dalam desa sendiri maupun dari luar desa. Musrembang adalah forum publik perencanaan (program) yang diselenggarakan oleh lembaga

Sadu Wasistiono, Kapita Selekta Manajemen Pemerintahan Daerah, Bandung: Alqaprint, 2001, hlm. 70.

19 Sony Walangitan, "Peranan Badan Pemusyawaratan Desa (BPD) dalam Perencanaan Pembangunan Desa (Suatu Studi di Desa Kanonang II Kecamatan Kawangkoan Barat)", hlm 1-23. https://media.neliti.com/media/ publications/1106-ID-peranan-badan-permusyawaratan-desa-bpd-dalam-perencanaan-pembangunan-desasuatu.pdf, diakses 11 September 2017. 
publik yaitu pemerintah desa atau kelurahan bekerjasama dengan warga dan para pemangku kepentingan. Penyelenggaraan musrenbang merupakan salah satu tugas pemerintah desa atau kelurahan untuk menyelenggarakan urusan pemerintahan, pembangunan dan kemasyarakatan.

Bintoro menyebutkan dengan perencanaan pembangunan dimaksudkan agar pembangunan terselenggara secara berencana, yaitu secara sadar, teratur, sistematis, berkesinambungan, mengusahakan peningkatan dan kemampuan menahan gojolak-gejolak di dalam pelaksanaannya. Agar usaha-usaha pembangunan dapat berhasil mencapai sasaran, maka pengarahan untuk pelaksanaan pembangunan dan pemanfaatan sumber-sumber yang ada perlu berpedoman pada suatu rencana yang terwujud dalam suatu bentuk perencanaan pembangunan. Hal ini tentu tidak terlepas dari: a) Perencanaan dalam arti seluas-luasnya tidak lain adalah suatu proses mempersiapkan secara sistematis kegiatan-kegiatan yang akan dilakukan untuk mencapai tujuan tertentu; b) Perencanaan adalah suatu cara bagaimana mencapai tujuan sebaik-baiknya (maksimal output) dengan sumber-sumber yang ada agar lebih efektif dan efisien; c) Perencanaan adalah penentuan tujuan yang akan dicapai atau yang akan dilaksanakan, bagaimana, bilamana, dan pada siapa; dan d) Perencanaan pembangunan adalah suatu pengarahan penggunaan sumber sumber pembangunan (termasuk sumber-sumber ekonomi) yang terbatas adanya untuk mencapai tujuan-tujuan sosial ekonomi yang lebih baik secara lebih efektif dan efisien. ${ }^{20}$

Dalam pencapaian tujuan mensejahterakan masyarakat desa, masing-masing unsur pemerintah desa dan BPD dapat menjalankan fungsinya dengan mendapat dukungan dari masyarakat setempat. Oleh karena itu, hubungan yang bersifat kemitraan antara BPD dengan pemerintah desa dalam pembangunan desa harus didasari pada filosofi antara lain: 1) adanya kedudukan yang sejajar diantara yang bermitra; 2) adanya kepentingan bersama yang ingin dicapai; 3) adanya prinsip saling menghormati; dan 4) adanya niat baik untuk membantu dan saling mengingatkan. ${ }^{21}$

\section{Peran Badan Permusyawaratan Desa dalam Pengawasan Keuangan Pemerintahan Desa}

Pasal 1 ayat (2) PP 60/2014 menyatakan bahwa dana desa adalah dana yang bersumber dari APBN yang diperuntukkan bagi desa yang ditransfer melalui APBD kabupaten/kota dan digunakan untuk membiayai penyelenggaraan pemerintahan, pelaksanaan pembangunan, pembinaan kemasyarakatan, dan pemberdayaan masyarakat. Selanjutnya dalam Pasal 6 dinyatakan bahwa dana desa tersebut ditransfer melalui APBD kabupaten/kota untuk selanjutnya ditransfer ke APB desa. Meskipun pemerintah telah meyakinkan agar masyarakat tidak khawatir mengenai penyelewengan dana desa tersebut tetapi dengan adanya fakta bahwa banyak kepala daerah terjerat kasus korupsi bukan tidak mungkin kalau ladang korupsi

20 Ibid.

21 Sadu Wasistiono dan Irawan Tohir, Prospek Pengembangan Desa, Bandung: CV Fokus Media, 2007, hlm. 36. 
itu akan berpindah ke desa-desa. Masyarakat desa sangat berharap agar BPD bisa menjalankan fungsinya untuk mengawasi penggunaan dana desa tersebut.

Pasal 55 UU Desa menyatakan: "BPD mempunyai fungsi yang salah satunya adalah pengawasan kinerja Kepala Desa". Sementara Pasal 48 Peraturan Pemerintah Nomor 43 Tahun 2014 tentang Peraturan Pelaksanaan Undang-Undang Nomor 6 Tahun 2014 tentang Desa (PP 43/2014) menyatakan bahwa dalam melaksanakan tugas, kewenangan, hak, dan kewajibannya, kepala desa wajib: a) menyampaikan laporan penyelenggaraan pemerintahan desa pada akhir masa jabatan kepada bupati/walikota; b) menyampaikan laporan penyelenggaraan pemerintahan desa setiap akhir tahun anggaran kepada bupati/walikota; c) menyampaikan laporan keterangan penyelenggaraan pemerintahan secara tertulis kepada BPD setiap akhir tahun anggaran. Selanjutnya dalam Pasal 51 PP 43/2014 dinyatakan bahwa kepala desa menyampaikan laporan keterangan penyelenggaraan pemerintahan desa sebagaimana dimaksud dalam Pasal 48 huruf c setiap akhir tahun anggaran, kepada BPD secara tertulis paling lambat 3 bulan setelah berakhirnya tahun anggaran. Laporan keterangan penyelenggaraan pemerintahan desa sebagaimana dimaksud pada ayat (1), paling sedikit memuat pelaksanaan peraturan desa. Laporan keterangan penyelenggaraan pemerintahan desa ini, digunakan oleh BPD dalam melaksanakan fungsi pengawasan kinerja kepala desa.

Dari uraian di atas, jelas bahwa BPD mempunyai peran yang strategis dalam ikut mengawal penggunaan dana desa tersebut, agar tidak diselewengkan. Jika dicermati ketentuan Pasal 48 dan Pasal 51 PP 43/2014, dalam peraturan pemerintah tersebut setikdanya ada 3 poin penting yang harus menjadi perhatian, yaitu: a) Pasal 48 huruf c yang menyebutkan bahwa kepala desa wajib menyampaikan laporan keterangan penyelenggaraan pemerintahan secara tertulis kepada BPD setiap akhir tahun anggaran; b) Pasal 51 ayat 2 bahwa laporan keterangan penyelenggaraan pemerintahan desa sebagaimana dimaksud pada ayat (1), paling sedikit memuat pelaksanaan peraturan desa; dan c) Lebih lanjut dalam Pasal 51 ayat (3) dijelaskan bahwa laporan keterangan penyelenggaraan pemerintahan desa sebagaimana dimaksud pada ayat (1) digunakan oleh BPD dalam melaksanakan fungsi pengawasan kinerja kepala desa.

Dari ketentuan di atas penting digaris-bawahi kata-kata 'paling sedikit' pada Pasal 51 ayat (2). Hal ini karena dalam laporan keterangan penyelenggaraan pemerintahan, salah satu dan utamanya mengenai pelaksanaan peraturan desa yang berisi tentang APB Desa. Ini artinya, bahwa kepala desa itu wajib membuat laporan keterangan tertulis tentang pelaksanaan peraturan desa tentang pelaksanaan APB Desa.

Karena dana desa yang bersumber dari APBN jumlahnya cukup besar, maka diperlukan mekanisme kontrol dari masyarakat untuk mengawasi penggunaan dana desa tersebut agar dipergunakan sesuai dengan peruntukannya untuk meningkatkan kesejahteraan masyarakat. Pemerintahan desa dituntut menyelenggarakan pemerintahan secara transparan dan akuntabel. BPD sebagai lembaga yang 
mempunyai fungsi pengawasan, diharapkan dapat menjalankan perannya secara sungguh-sungguh, terutama dalam hal penggunaan anggaran. Undang-undang dan peraturan pemerintah sudah memberikan payung hukum yang jelas, sehingga BPD tidak perlu ragu dalam menjalankan fungsinya melakukan pengawasan terhadap kinerja kepala desa. Adanya mekanisme 'check and balance' ini akan meminimalisasi penyalahgunaan keuangan desa. ${ }^{22}$

Perencanaan pembangunan desa disusun secara berjangka meliput RPJMDesa untuk jangka waktu 6 tahun. Perencanaan pembangunan desa ini didasarkan pada data dan informasi yang akurat dan dapat dipertanggungjawabkan. Data dan informasi tersebut mencakup penyelenggaraan pemerintahan desa, organisasi dan tata laksana pemerintahan desa, arah kebijakan pembangunan desa, keuangan desa, profil desa, informasi lain terkait dengan penyelenggaraan desa dan pemberdayaan masyarakat. Dalam mewujudkan kemandirian desa perlu dilaksanakan penyelenggaraan pemerintahan desa yang berorientasi pada transparansi, partisipasi, demokratisasi, dan pemberdayaan masyarakat desa yang merupakan tolak ukur penilaian pertanggungjawaban kinerja pemerintahan desa dalam kurun waktu tertentu.

Tugas pengawasan keuangan yang dilakukan oleh BPD juga harus diperhatikan setelah peraturan desa dihasilkan, supaya peraturan desa dapat berjalan dengan baik. Pelaksanaan pengawasan juga dapat mendeteksi sejauh mana kebijakan kepala desa untuk menjalankan dan sampai sejauh mana pula penyimpangan keuangan yang terjadi dalam pelaksanaan kerja tersebut. Ada beberapa kegiatan di dalam peran pengawasan keuangan yang dilakukan oleh BPD, yaitu: ${ }^{23}$

a) Pengendalian Keuangan, yakni suatu cara maupun metode yang dilakukan kepada individu ataupun kelompok agar prilaku dan tindakannya sesuai dengan nilai dan norma sosial yang dianut masyarakat. BPD diharapkan mampu menerapkan sebuah metode atau langkah yang efektif dalam menjalankan tugas pokok dan fungsinya sehingga mampu bersinergis dan adanya kesepahaman diantara individu-individu atau anggota lainnya. BPD sebagai unsur penyelenggaraan Pemerintah Desa dalam hal ini pelaksanaan pengawasan RPJM-Desa, oleh BPD terhadap rancangan yang dijalankan oleh kepala desa, sehingga terjadi hubungan kerja sama antara kedua lembaga desa tersebut, dalam hal ini kepala desa dan BPD;

b) Pengawasan Keuangan, yakni suatu upaya yang sistematik untuk menetapkan kinerja standar pada perencanaan untuk merancang sistem umpan balik informasi, untuk membandingkan kinerja aktual dengan standar yang telah ditentukan, untuk menetapkan apakah telah terjadi suatu penyimpangan tersebut, serta untuk mengambil tindakan perbaikan yang diperlukan untuk menjamin bahwa semua

22 Ngatiyat Priyambudi, "Dasar Hukum Pengawasan Dana Desa oleh BPD", http://www.keuangandesa. com/2015/05/dasar-hukum-pengawasan-dana-desa-oleh-bpd/, diakses 30 Agustus 2017.

23 Agus Saputra, "Peranan Badan Pemusyawaratan Desa (BPD) dalam Pengawasan Pelaksanaan Rencana Pembangunan Jangka Menengah Desa di Desa Kelumu Kecamatan Lingga Kabupaten Lingga Tahun 2011-2015", hlm. 1-23. http://jurnal.umrah.ac.id/wp-content/uploads/gravity_forms/1ec61c9cb232a03a96d0947c6478e525e/2016/08/jurnal-agus-saputra-pdf.pdf, diakses 30 Agustus 2017. 
sunber daya perusahaan atau pemerintahan telah digunakan secara efektif dan efisien, guna untuk mencapai suatu tujuan perusahaan ataupun pemerintahan. BPD adalah perwakilan masyarakat desa diharapkan mampu menjalankan tugas pokok dan fungsi dari pengawasan terhadap kebijakan-kebijakan yang telah ditetapkan dan disepakati bersama melalui RPJM-Desa apakah dapat berjalan sesuai dengan kesepakatan dan ketetapan bersama dalam musyawarah;

c) Pemantauan, kesadaran (awareness) adalah tentang apa yang ingin diketahui, pemantauan berkadar tingkat tinggi dilakukan agar dapat membuat pengukuran melalui waktu yang menunjukkan pergerakkan ke arah tujuan atau menjauh dari itu. BPD sebagai pelaksana pengawasan peraturan desa dan ketetapan Desa dalam menjalankan tugas pokok dan fungsinya perlu juga menerapkan dan melakukan pemantauan terhadap kebijakan-kebijakan yang sudah disepakati dan ditetapkan bersama sehingga dapat mencegah adanya penyimpangan. Dalam hal pemantauan, pihak BPD tidak dilibatkan secara penuh dalam pemantauan pelaksanaan program-program yang telah tertera didalam RPJM-Desa, terkesan pemerintah desa atau dalam hal ini kepala desa berjalan sendiri-sendiri sehingga tidak terjadi koordinasi atau tidak terjalin kerja sama pada kedua lembaga pemerintahan desa, Badan Permusyawaratan Desa hanya dilibatkan pada saat pembahasan alokasi dana desa saja;

d) Evaluasi, penilaian adalah suatu proses untuk mengambil keputusan dengan menggunakan informasi yang diperoleh melalui pengukuran hasil belajar baik yang menggunakan tes maupun non tes. BPD dalam menjalankan tugas pokok dan fungsinya perlu melakukan evaluasi menyeluruh terhadap kinerja yang sudah dijalankan sehingga dapat mengetahui sejauh mana keberhasilan dan kelemahan-kelemahan yang telah dilaksanakan dalam menjalankan tugas pokok dan fungsinya sehingga untuk kedepan berjalan secara efektif dan efisien, dimana antara pemerintah desa dan BPD sebagai unsur penyelenggara desa dapat bekerja secara profesional dalam pembangunan desa, dan target-target pembangunan tercapai sesuai dengan RPJM-Desa yang telah disepakati dan ditetapkan bersama unsur penyelenggara pemerintah desa;

e) Supervisi, yakni program pengukuran dan perbaikan dari kinerja kegiatan bawahan agar memastikan bahwa tujuan perusahaan atau pemerintahan dan rencana yang dirancang untuk mencapai mereka sedang dicapai. BPD diharapkan dalam menjalankan tugas pokok dan fungsinya untuk menerapkan supervisi didalam kinerjanya sehingga dapat mengupayakan langkah-langkah perbaikan dalam kinerja sehingga dapat mencegah penyimpangan-penyimpangan dan melakukan perbaikan terhadap kebijakan-kebijakan yang akan berjalan dan yang sedang berjalan sehingga mendapatkan hasil yang maksimal terhadap penerapan kebijakan-kebijakan yang telah disepakati dan ditetapkan bersama, ketika berbicara mengenai supervisi maka tidak bisa dilepaskan dari sumberdaya manusia dan keahlian dari aparatur pemerintahan desa, dengan harapan dapat dipahami tugas pokok dan fungsinya sebagai lembaga pengawas Pemerintah 
desa, di satu sisi peran masyarakat juga sangat dibutuhkan dalam pembangunan RPJM-Desa.

Selain itu BPD juga bisa melakukan pengawasan terkait: 1) Mengawasi semua tindakan yang dilakukan oleh pemerintah desa serta aspirasi yang telah disampaikan; 2) Jika terjadi penyelewengan, BPD memberikan teguran untuk pertama kali secara kekeluargaan; 3) BPD akan mengklarifikasi dalam rapat desa yang dipimpin oleh Ketua BPD; 4) Jika terjadi tindakan yang sangat sulit untuk dipecahkan, maka BPD akan memberikan sanksi atau peringatan sesuai yang telah diatur di dalam peraturan, seperti melaporkan kepada camat serta bupati untuk ditindaklanjuti. Adapun bentuk pengawasan yang dilakukan oleh BPD meliputi: 1) memantau semua pemasukan dan pengeluaran kas desa; 2) memantau secara rutin mengenai dana-dana swadaya yang digunakan untuk pembangunan desa; dan 3) pembangunan desa. Terkait efektivitas pengawasan BPD dalam mengawasi jalannya keuangan desa, dibutuhkan juga partisipasi dan kerja sama dari seluruh komponen masyarakat. ${ }^{24}$

Selain itu, faktor yang dapat mendukung pengawasan BPD adalah masyarakat. Masyarakat merupakan faktor penentu keberhasilan BPD dalam melaksanakan fungsinya. Besarnya dukungan, sambutan, dan penghargaan dari masyarakat kepada BPD, menjadikan BPD lebih mempunyai ruang gerak untuk dapat melaksanakan fungsinya. Dukungan dari masyarakat tidak hanya pada banyaknya aspirasi yang masuk, juga dari pelaksanaan suatu peraturan desa. Kemauan dan semangat dari masyarakatlah yang menjadikan segala keputusan BPD dan pemerintah desa, menjadi mudah untuk dilaksanakan. Partisipasi masyarakat, baik dalam bentuk aspirasi maupun dalam pelaksanaan suatu keputusan, sangat menentukan pelaksanaan tugas dan fungsi BPD. Namun demikian, kenyataannya tidak semua masyarakat menyukai kinerja BPD dikarenakan tidak semua keputusan yang ditetapkan oleh BPD dan pemerintah desa, dapat diterima oleh seluruh masyarakat. Beberapa kebijakan yang dikeluarkan terkadang mendapat respon yang beraneka ragam, baik pro maupun kontra dari masyarakat. Adanya tanggapan yang bersifat kontra, tentunya dapat menghambat langkah BPD dan pemerintah desa dalam pelaksanaan kebijakan tersebut.

\section{E. Penutup}

Peran BPD sebagai unsur penyelenggara pemerintahan desa memiliki posisi yang strategis dalam menjawab kebutuhan masyarakat sesuai dengan situasi dan kondisi masyarakat desa setempat. Perannya sangat besar dalam mempercepat keberhasilan pembangunan desa. Lebih-lebih dalam melaksanakan otonomi desa. Selain memahami dan mampu melaksanakan kedudukan, fungsi, wewenang, hak, dan kewajiban sesuai ketentuan yang berlaku, setiap anggota BPD harus benarbenar dapat menjadi lembaga tersebut sebagi saluran aspirasi masyarakat kepada

24 Christin Walukow, "Peranan Badan Permusyawaratan Desa Dalamz Pelaksanaan Fungsi Pengawasan (Suatu Studi Di Desa Kauneran Kecamatan Sonder Kabupaten Minahasa)”, Jurnal Eksekutif, Vol. 1, No. 7, 2016, hlm. 1-17. 
pemerintah desa. Sehingga pemerintahan desa dapat berjalan sesuai dengan yang diharapkan masyarakat desa. Oleh sebab itu, setiap anggota BPD juga harus mampu membaca kepentingan-kepentingan masyarakatnya. Menyalurkan aspirasi serta menjembatani apa yang menjadi kebutuhan masyarakat desa.

Peran BPD dalam pembangunan desa sangatlah vital. Pembangunan desa bertujuan meningkatkan kesejahteraan masyarakat desa dan kualitas hidup manusia serta penanggulangan kemiskinan melalui pemenuhan kebutuhan dasar, pembangunan sarana dan prasarana desa, pengembangan potensi ekonomi lokal, serta pemanfaatan sumber daya alam, dan lingkungan secara berkelanjutan. Pembangunan desa meliputi tahap perencanaan, pelaksanaan, dan pengawasan. Dalam pencapaian tujuan mensejahterakan masyarakat desa, BPD dapat menjalankan fungsinya dengan mendapat dukungan dari masyarakat setempat. Tugas pengawasan keuangan yang dilakukan oleh BPD juga harus diperhatikan setelah peraturan desa dihasilkan agar peraturan desa dapat berjalan dengan baik. Pelaksanaan pengawasan juga dapat mendeteksi sejauhmana kebijakan kepala desa untuk menjalankan dan sampai sejauhmana pula penyimpangan keuangan yang terjadi dalam pelaksanaan kerja tersebut. Selain itu faktor yang dapat mendukung pengawasan BPD adalah masyarakat, karena masyarakat merupakan faktor penentu keberhasilan BPD dalam melaksanakan pengawasan keuangan desa.

\section{Daftar Pustaka}

Buku

Andi Mustari Pide, Otonomi Daerah dan Kepala Daerah Memasuki Abad XXI, Gaya Media Pratama, Jakarta, 1999.

Ateng Syafrudin dan Suprin Na'a, Republik Desa: Pergulatan Hukum Tradisional dan Hukum Modern Dalam Desain Otonomi Desa, Alumni, Bandung, 2010.

A. Surjadi, Pembangunan Masyarakat Desa, Mandar Maju, Bandung, 1995.

A. T Soegito, Prof. Mr. Dr. R. Soepomo, Departemen Pendidikan dan Kebudayaan Pusat Penelitian Sejarah dan Budaya Proyek Investarisasi dan Dokumen Sejarah Nasional, Jakarta-Indonesia, 1979-1980.

Bagir Manan, Menyongsong Fajar Otonomi Daerah, Yogyakarta: Pusat Studi Hukum Fakultas UII Yogyakarta, 2002.

Didik Sukrino, Hukum Konstitusi dan Konsep Otonomi, Kajian Politik Hukum Tentang Konstitusi, Otonomi Daerah dan Desa Pasca Perubahan Konstitusi, Setara Press, Malang, 2013.

I Gde Pantja Astawa, Problematika Otonomi di Daerah di Indonesia, Alumni, Bandung, 2013.

J. Kaloh, Mencari Bentuk Otonomi Daerah, Suatu Solusi Dalam Menjawab Kebutuhan Lokal dan Tantangan Global, PT. Rineka Cipta, Jakarta, 2007.

Sadu Wasistiono, Kapita Selekta Manajemen Pemerintahan Daerah, Alqaprint, Bandung, 2001. 
dan Irawan Tohir, Prospek Pengembangan Desa, CV. Fokus Media,

Bandung, 2007.

\section{Dokumen Lain}

A. Hamid S Attamimi, "Peranan Keputusan Presiden Republik Indonesia dalam Penyelenggaraan Pemerintahan Negara, Suatu Studi Analisis Mengenai Keputusan Presiden yang Berfungsi Pengaturan dalam Ukuran Waktu Pelita I-IV", Disertasi, Pascasarjana Fakultas Hukum Universitas Indonesia, Jakarta, 1990.

Agus Saputra, "Peranan Badan Pemusyawaratan Desa (BPD) dalam Pengawasan Pelaksanaan Rencana Pembangunan Jangka Menengah Desa di Desa Kelumu Kecamatan Lingga Kabupaten Lingga Tahun 20112015", http://jurnal.umrah.ac.id/wp-content/uploads/gravity_forms/1ec61c9cb232a03a96d0947c6478e525e/2016/08/Jurnal-Agus-Saputra-Pdf.Pdf, diakses 30 Agustus 2017.

Andri Paraso, "Efektivitas Badan Permusyawaratan Desa dalam Penyelenggaraan Pengwasan Pemerintahan di Desa Sareh (Suatu Studi di Desa Sereh Kecamatan Lirung Kabupaten Kepulauan Talaud)", Jurnal Eksekutif, Vol. 2, No. 1, 2013.

Christin Walukow, "Peranan Badan Permusyawaratan Desa Dalam Pelaksanaan Fungsi Pengawasan (Suatu Studi Di Desa Kauneran Kecamatan Sonder Kabupaten Minahasa)", Jurnal Eksekutif, Vol. 1, No. 7, 2016.

Dian Haryani, "Peran Badan Permusyawaratan Desa Dalam Pengawasan Penyelenggaraan Pemerintahan Desa di Desa Melati II Kecamatan Perbaungan Kabupaten Serdang Bedagai", Jurnal Perspektif, Vol. 8, No. 1, 2015.

Findy Yanel Mamesah, "Peranan Badan Permusyawaratan Desa dalam Penyusunan Anggaran Pendapatan dan Belanja Daerah (Suatu Studi di Desa Sendangan Kecamatan Tompaso)", Skripsi, Fakultas Hukum Universitas Samratulangi, Manado, 2014.

Kamus Besar Bahasa Indonesia, "Peran”, https://kbbi.kemdikbud.go.id/entri/peran diakses 11 September 2017.

Ngatiyat Priyambudi, “Dasar Hukum Pengawasan Dana Desa oleh BPD”, http://www. keuangandesa.com/2015/05/dasar-hukum-pengawasan-dana-desa-oleh-bpd/, diakses 30 Agustus 2017.

Robi Syafwar, "Pengawasan Pengelolaan Keuangan Nagari Oleh Badan Permusyawaratan Nagari Di Kabupaten Agam", Tesis, Pascasarjana Fakultas Hukum Universitas Andalas, Padang, 2017.

Sony Walangitan, "Peranan Badan Pemusyawaratan Desa (BPD) dalam Perencanaan Pembangunan Desa (Suatu Studi di Desa Kanonang II Kecamatan Kawangkoan Barat)", https://media.neliti.com/media/publications/1106-ID-peranan-badanpermusyawaratan-desa-bpd-dalam-perencanaan-pembangunan-desa-suatu. pdf, diakses 11 September 2017. 


\section{Dokumen Hukum}

Undang-Undang Nomor 6 Tahun 2014 tentang Desa.

Undang-Undang Nomor 23 Tahun 2014 tentang Pemerintahan Daerah.

Peraturan Pemerintah Nomor 43 Tahun 2014 tentang Peraturan Pelaksanaan Undang-Undang Nomor 6 Tahun 2014 tentang Desa.

Peraturan Pemerintah Nomor 60 Tahun 2014 tentang Dana Desa yang Bersumber dari Anggaran Pendapatan Belanja Negara. 